\title{
A Survey of College Student Dormitory Lifestyle and Related Management Strategies
}

\author{
Wenzhu Wei ${ }^{1} \&$ Li Chen $^{1}$ \\ ${ }^{1}$ School of Education, Sichuan Normal University, Chengdu, China \\ Correspondence: Wenzhu Wei, School of Education, Sichuan Normal University, Chengdu 610066, Sichuan, \\ China.
}

Received: March 19, 2019

Accepted: April 9, 2019

Online Published: April 25, 2019

doi:10.20849/aes.v4i1.567

URL: https://doi.org/10.20849/aes.v4i1.567

\begin{abstract}
A systematic survey on the life-style of college undergraduate dormitory of a local public university finds that, most of the time, undergraduates "amuse themselves" in the dorms and mutual learning and communication time is relatively insufficient. Students in the dorms have a higher expectation on interpersonal relationship. However, in reality, there exists the problem that the affection between them is indifferent. Besides, when they come into conflicts, they are incapable of resolving the conflicts through a normal channel. Furthermore, students are relatively satisfied with the life service in dormitory management, while they are not satisfied with the hardware facilities and the rules and regulations. To improve the management level of college student dormitory and promote development of students, it is necessary for the department of college dormitory management to strengthen construction of the physical environment, develop an organic dormitory interpersonal network and establish the dormitory organizational structure and institutional norms in which students can participate. Above all, the department of dormitory management needs to establish the system of dormitory education to help students carry out effective education in life.
\end{abstract}

Keywords: lifestyle, dormitory management, life education

\section{Introduction}

Centralized dormitory system is a general phenomenon in Chinese universities and colleges. The Ministry of Education has, more than once, issued documents to strengthen college student dormitory management and to prohibit students from renting off campus. In 2007, "Notice on Further Improvement of College Student Dormitory Management by the General Office of Ministry of Education" (Office of Education, Thought and Politics (2007) No. 4) pointed out, "Organizing students in the same class to get accommodation is an effective way in conducting student education and management at present". Existing researchers have improved the indoor environment of university dormitories in winter, improved the dormitory security by using smart home and face recognition system, and tried to improve the educational function of dormitory management through the integration of Ideological and political education. Thus, it can be found that, student dormitory is deemed to undertake a life function, a management function and an education function and is a significant educational resource for promoting overall development of college students. Karl Marx and Friedrich Engels pointed out in "Feuerbach", "The way in which an individual shows himself in his life indicates how he behaves himself. Therefore, how an individual behaves himself (Karl Marx \& Friedrich Engels, 1972, p.25), namely, the lifestyle of an individual is a mirror of "what kind of person he is". It is obvious that understanding college students" lifestyle in the dormitory helps to get more information about basic characteristics of the entire group and reveal the existing issues in the current student dormitory management mode. This, furthermore, promotes improvement of college student dormitory management mode and the entire college student cultivation mode.

\section{Research Design}

\subsection{Connotation and Structure of Lifestyle}

Not only does lifestyle reflect what kind of person an individual is, but also it is an important mechanism for formation of a group. "Consistence of lifestyle forms a status group, while the status group can be divided into two mechanisms of internal cohesion and external exclusion". (Gao, Bingzhong, 1998, p.61) Lifestyle plays an important role in formation and maintenance of individuals and groups. As for the connotation of lifestyle, Max 
Weber says "Lifestyle is a series of living habits, life attitudes and life systems which are formed under the influences of certain culture, nationality, economy, society, customs and regulations for a long period of time. Lifestyle includes personal hobby, cognitive style and behavioral activities during the spare time." Thus, it can be seen that the connotation of lifestyle is extremely plentiful and can even be said to cover all aspects in human social life.

In order to further clarify the structure of college students' lifestyle, the researcher conducted a semi-structured interview with the objects in her own dormitory, in her friends' dormitories as well as in the QQ group of her class at the early stage of the survey. The content of the interview was an extensive discussion on the issues of activities in the dormitory, atmosphere of the dormitory, interpersonal relationship in the dormitory and management of the dormitory, etc. Through a statistical survey on the frequently used words, three major aspects in the lifestyle of college student dormitory are established, namely, time arrangement of an individual in the dormitory, interpersonal relationship in the dormitory and the attitude of an individual towards the current management system.

\subsection{Selection of Samples}

This study takes undergraduate dormitory in Sichuan Normal University as the research object. Sichuan Normal University is a local general public university. It has more than 35,000 full time undergraduates who are mainly arts and science students. Local general public university is a sort of universities and colleges which have the maximum number currently in China. Besides, under the influence of grand unification in higher educational management mode for a long period of time, the management mode of student dormitory in Sichuan Normal University is of particular representativeness and typicality. Selection of Sichuan Normal University as a case study also abides by the principle of convenience. Furthermore, all the investigators in this research are teachers and students in this university, so they are more close to the research objects and are capable of providing a perspective of an insider.

\subsection{Research Method}

This study adopts a method of combining questionnaire survey and in-depth interview. The researchers discovered at the earlier stage of the survey that activities of students in the dormitory were extremely diversified. Therefore, if structural questionnaire was used in the survey, the data presentation might be relatively distinct and easier to process. Meanwhile, this might as well sacrifice the complexity and diversity of the research objects. Hence, the researchers finally decided to adopt semi-structural questionnaire for the survey.

The questionnaire is mainly comprised of four parts. The first part includes the basic information of the research objects, such as, grade, gender and major. The second part is the mean time of all kinds of activities in the dormitory. Ten frequent dormitory activities are listed according to the interview at the earlier stage. The third part is an investigation on the interpersonal relationship in the dormitory, which includes students' evaluation on the interpersonal relationship in the dormitory and the resolutions to problems arising in the interpersonal relationship. The fourth part is an open-ended question about the attitude towards the management system of the college dormitory.

Since the questionnaire structure is comparatively complicated, all the answers require much thinking from the research objects, let alone calculation of the time of daily activities in the dormitory. Thus, in order to ensure the quality of the questionnaire, after the researchers made a stratified sampling of the three variables of gender, grade and discipline to determine the scope of dormitories, they went to the dormitories to let the research objects fill in the questionnaire face to face and then took back the questionnaire face to face. Altogether, 154 questionnaires were sent out and taken back. The data statistics was conducted with the statistical software SPSS16.0.

Gender: 80 female students, accounting for 51.9\%; 74 male students, accounting for $48.1 \%$.

Major: 82 students of liberal arts, accounting for $53.2 \%$; 72 students of science and engineering, accounting for 46.8\%. (Since most majors in Sichuan Normal University are arts and sciences and there is only a small number of engineering majors which are also partial to sciences, this research synthesizes science majors with engineering majors.)

Grades: 38 students from the grade of freshman, accounting for $24.7 \%$; 38 students from the grade of sophomore, accounting for $24.7 \%$; 46 students from the grade of junior, accounting for $29.9 \%$; 32 students from the grade of senior, accounting for $20.8 \%$.

The three variables of gender, major and grade are almost in balance. 


\section{Result of Survey}

\subsection{Dormitory Is the Main Activity Occasion of College Students, Primarily Individualized Entertainment} Activities

\section{The average time of activities in student dormitory each day}

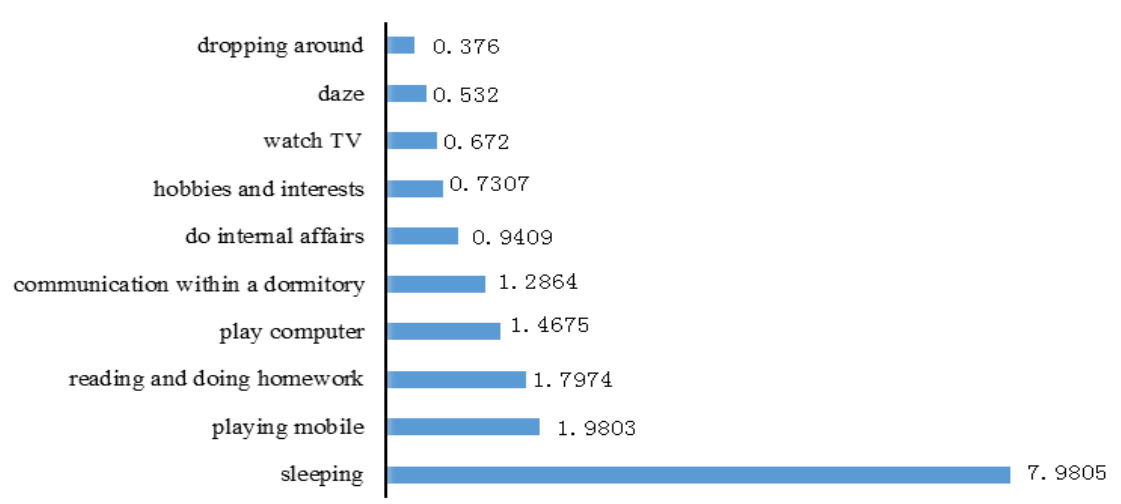

Figure 1. Statistical time of students' activities in the dormitory (Unit: Hour)

As shown in Figure 1, the average time of activities in student dormitory reaches 17.7637 hours, whereas the time of activities outside the dormitory is merely 6 hours. Without doubt, dormitory is a primary activity occasion for college students. The situation of students' living and learning in the dormitory can greatly reflect or influence their college lifestyle.

The average time of sleeping among university students is 7.9805 hours. This approximately conforms to the sleeping time required for a healthy lifestyle by an adult.

"Playing mobile" is an activity which occupies the most time of college students in the dormitory in addition to sleeping. With popularity of smart phone, "flooding the screen" has become the most popular lifestyle among young people, including chatting, reading news and playing games with mobile phone. With such software as QQ and WeChat, mobile phone has become the most influential "We Media". In addition to "playing mobile", the average time spent on "using the computer" in the dormitory is 1.3625 hours among college students. The time used together in "playing mobile" and "using the computer" is close to 3.5 hours. It can be said that, network has become the primary lifestyle among young people in the current society. In addition to social activities, shopping and learning are also done through the network. Therefore, it is necessary to change the traditional concept and develop new instrument to make full use of the network and to undertake educational management and teaching. Comparatively speaking, the status of "watching TV" has declined sharply in the college dormitory which, in the past, was the most common indoor entertainment activity. The average time spent on watching TV each day by all interviewees is only 0.6720 hour. The number of students who spend no more than 30 minutes on watching TV accounts for $60 \%$, and even $45.3 \%$ of students say they never watch TV in the dormitory.

The average time spent each day by undergraduates in Sichuan Normal University on such learning activities as reading and doing homework in the dormitory is 1.7974 hours, which approximately occupies one fifth of the total time of activities in the dormitory excluding sleeping. The relation between major and gender and the time spent on learning in the dormitory can be found as in the following figure. 


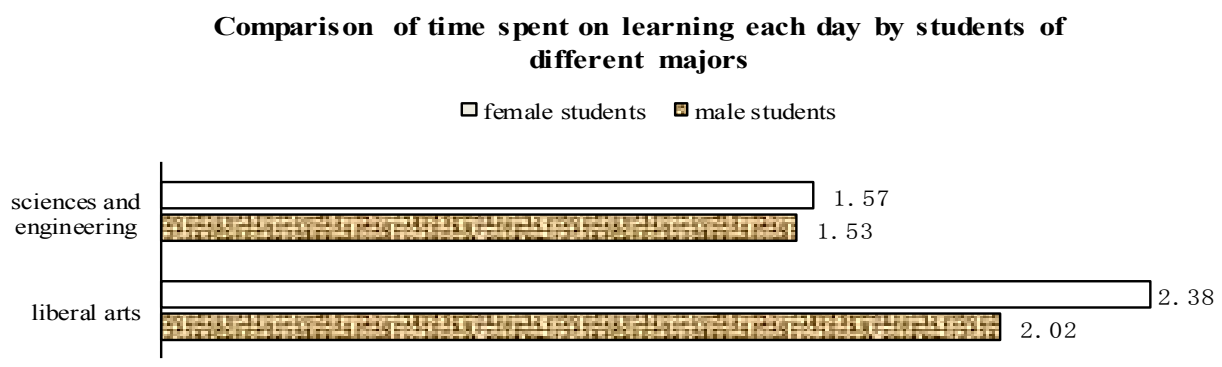

Figure 2. Hours spent each day on such learning as reading and doing homework in the dormitory (Unit: Hour)

As shown in Figure 2, it is a general phenomenon that students of liberal arts spend more time on learning in the dormitory than students of science and engineering and female students spend more time on learning in the dormitory than male students. The time spent on learning in the dormitory by female students of liberal arts is the most, while the time spent on learning in the dormitory by male and female students of science and engineering is of no difference. The major learning style of students of liberal arts is relatively independent reading, writing and introspection, whereas students of science and engineering spend more time on making experiment. Hence, the time spent on learning in the dormitory by students of liberal arts is obviously more than students of science and engineering. Students of different majors have different demands on the space of dormitory in terms of learning style and learning content. Also, the factor of gender of students influences the demands on dormitory functions. This may necessitate providing dormitories of different conditions for students from different majors and of different genders.

The existing college student dormitories in Sichuan Normal University were all constructed between 1970s and the end of 1990s, which include the three sorts of dormitories respectively with 4 rooms, 6 rooms and 8 rooms. As a kind of group dormitory, interpersonal communication inside and outside the dormitory is inevitable. During the survey, four students said the time they spent on the interpersonal communication in the dormitory was 0 . That means they have no communication at all with their roommates. As a whole, the number of students who communicate with other roommates in the dormitory for no more than 1 hour account for $23.4 \%$ of the total. There are two students who, compared with other students, spend the most time on communication in the dormitory, communicating each day with their roommates as long as five hours. The mean time of communication within the student dormitory is 1.2864 hours, with a median of 1 hour and a standard deviation of 0.91801 . Thus, it can be seen that great distinction exists in interpersonal communication in the dormitory. As all undergraduate dormitories in Sichuan Normal University have a barrack-like structure and the floor passages are slotted, there is almost no barrier between dormitories from the perspective of physical spatial structure. However, from the perspective of social structure, communication across different dormitories in the university is extremely rare. The questionnaire survey shows, the average time spent on dropping around between dormitories is 0.3760 hour and the standard deviation is 0.41650 . Besides, there are $42.7 \%$ students who never drop around and the proportion of students who drop around each day for no more than 0.5 hour reaches $81.3 \%$. Thus, it can be found that great distinction exists in the time spent by students on dropping around. However, on a whole, communication across dormitories on the same floor is extremely rate.

At the earlier stage of the open-ended interview, some students mentioned an extremely important dormitory activity - daze. Data in the questionnaire survey show that the average time of daze among students in the dormitory exceeds half an hour -0.5320 hour, and the most time of daze in the dormitory even reaches as much as 3 hours. It is reported, "dazing" leisure is currently in vogue. On December 13, 2017, the 5th International Daze Competition was held in Taiwan Station of China. The male students of Hong Kong University of Science and Technology won the championship. Competition judges believe that "dazing " can calm the body, help improve attention and alleviate anxiety. As a kind of fashionable leisure mode in the modern society, "daze" also exists in college student dormitory. This indicates that the lifestyle of university students synchronizes with the lifestyle of the entire society. At the same time, it proves that dormitory is, indeed, a secure occasion which 
makes quite a large portion of students feel relaxed.

In addition to rest, learning and communication, the time students spend on such hobbies and interests as drawing, handcraft, calligraphy and playing stringed instruments is 0.7307 hour, with a standard deviation of 0.88348. Thus, it follows that the time students spend on hobbies and interests in the dormitory is not much and great difference exists as the time spent by students of liberal arts is twice than that of students of sciences. We integrate the 10 activities of students in the dormitory into the four aspects of rest (including sleeping and doing internal affairs), learning, communication (communication both inside and outside the dormitory) self-entertainment (playing mobile phone, playing computer, watching TV, daze, and hobbies and interests). Accordingly, the time of activities is shown as in Table 1.

Table 1. Allocation of time of activities in the dormitory (Unit: Hour)

\begin{tabular}{|c|c|c|c|c|c|c|c|c|}
\hline & \multicolumn{2}{|l|}{ Gender } & \multicolumn{2}{|c|}{ Discipline } & \multicolumn{4}{|l|}{ Grade } \\
\hline & $\begin{array}{l}\text { Male } \\
\text { students }\end{array}$ & $\begin{array}{l}\text { Female } \\
\text { students }\end{array}$ & $\begin{array}{l}\text { Liberal } \\
\text { arts }\end{array}$ & $\begin{array}{l}\text { Science } \\
\mathrm{S}\end{array}$ & Freshman & $\begin{array}{l}\text { Sophomor } \\
\text { e }\end{array}$ & $\begin{array}{l}\text { Junio } \\
\mathrm{r}\end{array}$ & Senior \\
\hline Rest & 8.79 & 9.04 & 8.90 & 8.95 & 8.47 & 8.41 & 9.51 & 9.29 \\
\hline Self-entertainment & 4.63 & 4.67 & 4.96 & 4.31 & 4.69 & 3.90 & 5.16 & 4.77 \\
\hline Communication & 1.75 & 1.59 & 1.73 & 1.59 & 1.57 & 1.45 & 1.92 & 1.65 \\
\hline Learning & 2.44 & 2.60 & 3.20 & 1.74 & 2.59 & 2.10 & 2.34 & 3.22 \\
\hline
\end{tabular}

As shown in Table 1, the time students spend in the dormitory is also correlated with grade in addition to major and gender. Senior students spend more time in the dormitory, whereas sophomore students spend the least time in the dormitory. This might have something to do with arrangement of courses in different grades. On the whole, self-entertainment is the major mode of activities in college student dormitory in addition to rest. However, interpersonal relationship in the dormitory is insufficient. The activity of learning in the dormitory differs considerably among students of different majors and the overall time of learning is still less. Thus, it can be seen that a large majority of student still believe dormitory is a primary rest and recreation occasion instead of a venue for learning.

\subsection{The Overall Interpersonal Relationship Within the Dormitory Is Harmonious and Contradictions Is Mainly Resolved Within the Dormitory}

The questionnaire survey indicates interpersonal communication in college student dormitory is lacking, but students' overall evaluation on their interpersonal relationship in the dormitory is relatively good.

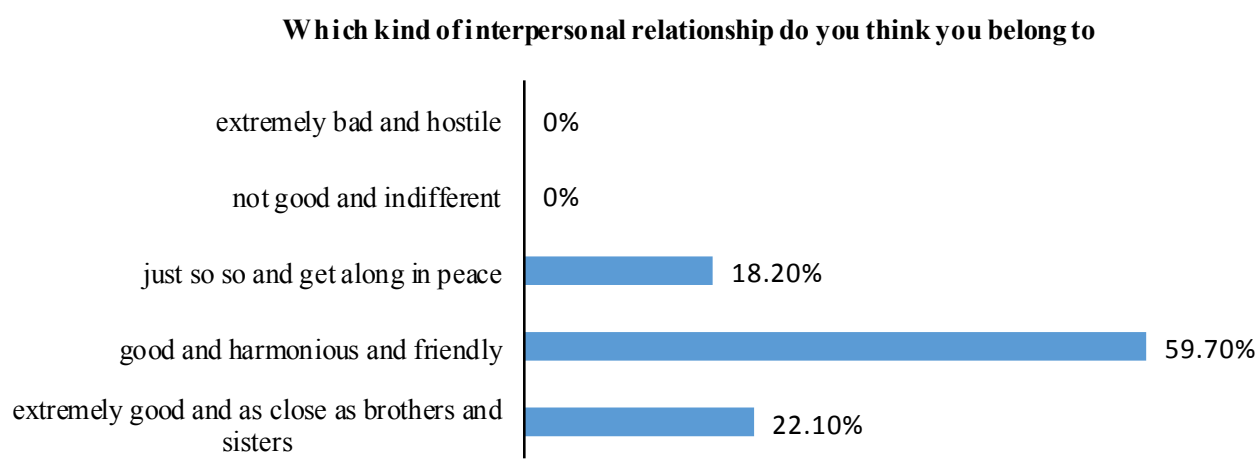

Figure 3. Condition of interpersonal relationship in the dormitory

As shown in Figure 3, in the questionnaire survey, no student chose the two options of "not good and indifferent" and "extremely bad and hostile". This does not conform to previous survey on time of activities in which four 
students chose had no communication at all with their roommates and more than $23 \%$ roommates had no more than one hour of communication each day with each other. In order to interpret this contradiction about the data, we interviewed 20 students by means of QQ through the network. And their explanation can be roughly classified into the following several statements:

"We have no talking at ordinary times in the dormitory, but we communicate on the network".

"If we don't get along well, we just have no talking and there is no need to become foes"

"Since you see them filling in the questionnaire face to face, no one would be willing to let others know they don't get along well in the dormitory"

It is known from the interview that there are mainly three reasons for contradictions between the data of activity time and that of evaluation on interpersonal relationship. One reason is change of communication modes as online communication replaces offline communication. The second reason is that students attach no importance to the interpersonal relationship in the dormitory and believe it doesn't matter at all even if the relationship is not good. The third reason is that the technical means used in the survey are not appropriate. For the purpose of better understanding the plentifulness and complexity of students' lifestyle in the dormitory, the researchers used semi-structural questions which required careful thinking by the respondents. To guarantee quality of the questionnaire, the researchers were usually required to accompany with the respondents to finish the questionnaire. This resulted in the fact that some respondents intentionally concealed their actual idea in answering the question that required "declaring their attitude". Of course, this situation also proves that the students believe bad interpersonal relationship in the dormitory is an "unpleasant thing" and has nothing to do with "face". This, from another perspective, also mirrors students" expectation on a good interpersonal relationship.

Then, how to resolve the contradictions in interpersonal relationship in the dormitory?

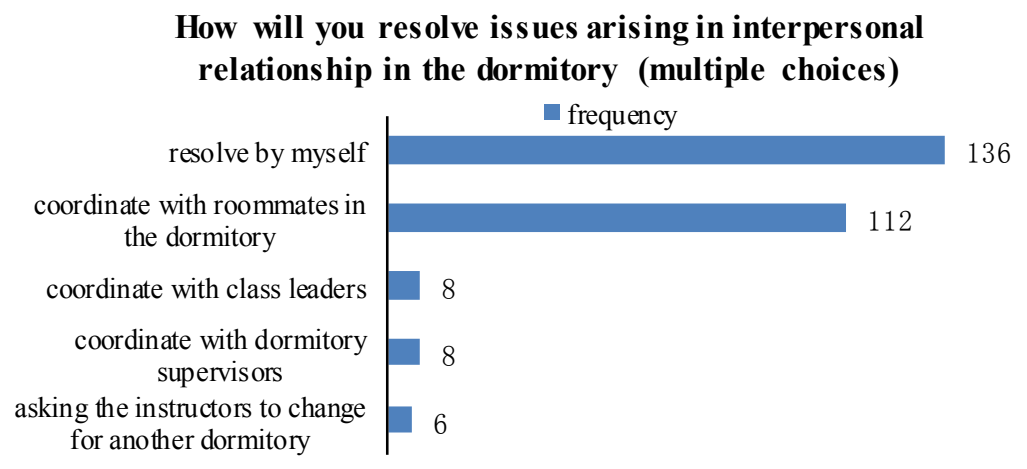

Figure 4. Resolutions to issues arising in interpersonal relationship in the dormitory

As shown in Figure 4, when contradictions arise in interpersonal relationship in the dormitory, students tend to resolve by themselves or coordinate with their roommates. They seldom choose to resolve the contradictions by resorting to such official approaches as the class leaders, dormitory supervisors or the instructors. So to speak, when contradictions arise within a dormitory, the students mainly resolve by unofficial means as there has not had any institutionalized or standardized dormitory contradiction resolution mechanism. After the poisoning case occurred earlier in 2013 in Fudan University in China, a buzzword was popular among university students ---"Thank my roommates for sparing my life". On the basis of its survey, China Youth News pointed out "An inharmonious relationship exists in the dormitory in a lot of universities and colleges". (Zhu, Liya, \& Xie, Jinnan, 2013) Thus, it can be seen that the interpersonal relationship in college student dormitory is not as perfect as it appears. Nevertheless, the current institutional design fails to meet the need of students to resolve issues by official means.

\subsection{Life Service Is What Students Are Most Satisfied With Dormitory Management, Whereas Hardware Facilities and Rules and Regulations Are What They Are Most Dissatisfied With}

The last section of the questionnaire survey is open-ended questions which mainly investigate the aspects 
students are satisfied and unsatisfied with dormitory management. Answers to these two open-ended questions are relatively diversified, so we make a statistical classification of the answers to the questionnaire.

Table 2. Attitudes of students towards dormitory management (Unit: Number of times)

\begin{tabular}{llllllllll}
\hline $\begin{array}{l}\text { Items } \\
\text { Attitu } \\
\text { des }\end{array}$ & $\begin{array}{l}\text { Managem } \\
\text { ent of } \begin{array}{r}\text { Hardw } \\
\text { water and } \\
\text { electricity }\end{array}\end{array}$ & $\begin{array}{l}\text { Rules } \\
\text { and }\end{array}$ & $\begin{array}{l}\text { Security } \\
\text { adminis } \\
\text { regulati } \\
\text { tration }\end{array}$ & $\begin{array}{l}\text { Mainten } \\
\text { ance } \\
\text { manage } \\
\text { ment }\end{array}$ & $\begin{array}{l}\text { Attitude } \\
\text { of } \\
\text { service } \\
\text { staff }\end{array}$ & $\begin{array}{l}\text { Management } \\
\text { of life order }\end{array}$ & $\begin{array}{l}\text { Sanitary } \\
\text { control }\end{array}$ & $\begin{array}{l}\text { Management } \\
\text { of dormitory } \\
\text { allocation }\end{array}$ \\
\hline $\begin{array}{l}\text { Satisf } \\
\text { ied }\end{array}$ & 20 & 12 & - & 4 & 8 & 40 & 40 & 38 & 4 \\
\hline $\begin{array}{l}\text { Unsat } \\
\text { isfied }\end{array}$ & 64 & 58 & 44 & 26 & 6 & 2 & - & - & - \\
\hline
\end{tabular}

Table 2 shows the three aspects students are most satisfied with dormitory management, namely, attitude of service staff (enthusiasm and responsibility of the aunts in the dormitory), life order (stipulated work and rest time, management in order and periodic inspection on dormitory hygiene, etc.) and sanitary control (cleaning up). As a matter of act, all these three aspects fall within the scope of life service. Hence, it is obvious that students are relatively satisfied with the service management in the student dormitory in Sichuan Normal University.

The three aspects which students are most dissatisfied with are management of water and electricity (small number of hot water rooms, unreasonable poweroff in the evening, etc.), hardware facilities (out-of-service lavatory now and then, lack of air conditioner, congested dormitory space, poor dormitory conditions, lack of study rooms, failure to air a quilt, and small number of washing machines) and rules and regulations (rounding for dormitory, putting down names if coming back late, strict disposal for violation of using electrical appliance, too many rules, prohibition to using electric hair drier, etc.). This mainly involves hardware facilities in the dormitory and freedom of students' activities in the dormitory. In the interview, it is a general phenomenon that students mention "humanization is lacking in management" and "too strict management". However, their opinions vary in terms of humanized management".

\section{Conclusions and Suggestions}

Through questionnaire survey and interview, it is found that the lifestyle of students in the dormitory in Sichuan Normal University is mainly "self-entertainment". However, interpersonal relationship is till alienated and dormitory management still remains on the level of satisfying basic living needs and "keeping safe". Such a lifestyle and model of dormitory management are universal across all universities and colleges in the country. Then, what kind of dormitory lifestyle is healthy and helpful to students' development? What kind of functions a college student dormitory is expected to undertake in modern university education? In 2008, US scholars put forward two major functions that a university dormitory was assumed to have --- function of management and function of education. Table 1 shows, the first three levels emphasize physical environment and belong to equipment orientation which mainly reflect the function of management. The last two levels emphasize interpersonal environment and belong to student orientation which reflect the function of education.

Table 3. Functions and levels of student dormitories in US universities and colleges $\mathrm{Xu}, \mathrm{Bo}, \&$ Cang, Yuquan, 2004, p.96)

\begin{tabular}{llll}
\hline $\begin{array}{l}\text { Physical } \\
\text { environment }\end{array}$ & $\begin{array}{l}\text { Level 1: building and repairing the dormitory and providing a } \\
\text { comfortable physical environment }\end{array}$ & Function \\
\cline { 2 - 2 } $\begin{array}{l}\text { Equipment } \\
\text { orientation) }\end{array}$ & Level 2: better repairing and maintaining all kinds of equipment & of \\
& $\begin{array}{l}\text { Level 3: establishing dormitory rules of coexistence and } \\
\text { cooperation }\end{array}$ & \\
\hline $\begin{array}{l}\text { Interpersonal } \\
\text { environment }\end{array}$ & $\begin{array}{l}\text { Level 4: setting up an environment of mutual caring, being } \\
\text { helpful to learning and common sense }\end{array}$ & \\
\cline { 2 - 3 } $\begin{array}{l}\text { Student } \\
\text { orientation) }\end{array}$ & $\begin{array}{l}\text { Level 5: offering a lot of opportunities that are helpful to } \\
\text { individual growth and development }\end{array}$ & \\
\hline
\end{tabular}


Comparing this table, it is not difficult to find that student dormitory management in Chinese universities and colleges still have a long way to go both in terms of establishment of physical environment and in terms of interpersonal relationship. As a result, neither the function of management nor the function of education can be exerted well. In order to improve college student dormitory management and promote development of students, we need to carry on reforms on the following several aspects.

\subsection{First of All, It Is Necessary to Strengthen Establishment of Physical Environment}

As a matter of fact, temporal structure is reflection of spatial structure and spatial structure basically determines the modes of activities within the space. It is demonstrated in a study that if planning of buildings in universities and colleges is perfect, the positive environmental perception of students is better and the negative environmental perception (such as sense of crowding) is worse. As such, more positive behaviors of students and fewer negative behaviors are seen. (Yan, Xiongzhong, Hu, Tiehui, \& Liu, Ddaoqiang, 2006, p.72) It is found in this survey that students are seriously dissatisfied with hardware facilities and management system of dormitories in their subjective perception. In their objective behaviors, students spend little time in independent learning and mutual communication with dormitory members in the dormitory although dormitory is a venue of activities on which students spend the most time. Therefore, it is quite necessary is strengthen establishment of physical environment.

Establishment of a favorable physical environment needs to commence from two aspects. On one hand, it is necessary to diminish the population density of students in the dormitory and try to realize the "four-two-one" construction target (four undergraduates in one room, two mater students in one room and one doctoral student in one room) of college student dormitories put forward by the Ministry of Education in 2000. It is also necessary to provide students with a relatively private space because privacy belongs to the scope of human security demand and necessary privacy helps to form a healthy psychology of students. On the other hand, it is necessary to furnish essential public activities occasions within the dormitory area. For instance, it is a good choice to set up such public venues as study rooms and reception areas within the dormitory building so as to meet up with the needs of students in living and social intercourse. Some researchers have discussed the community management of College Students' apartments in order to promote the healthy development of College students. Since activity modes in student dormitory are affected by the factors of gender, major and grade, the university may take into account furnishing students of different majors and genders with appropriate dormitories to meet up students' needs in learning and other aspects of development if the condition allows. In short, the target of establishment of physical environment is not only to allow students to "reside" in the dormitory, but also "live" with health and joy in the dormitory.

\subsection{Secondly, It Is Necessary to Construct an Organic Dormitory Interpersonal Relationship Network and Set up an Organic Structure and Institutional Norms for Students to Participate in Dormitory Governance}

If we say that Chinese college student dormitory is still primarily a place for sleeping and rest, then what sort of college student dormitory are in foreign countries? "College student dormitory in Germany is not merely a shelter, but also an occasion for social intercourse. Indeed, styles of each block, each floor and even each room in college dormitories in Germany vary. Some dormitories are constructed by integrating multi cultures of both eastern and western countries; some are constructed with the background of Christian civilization; some are well known for environmental protection; and still some are based on hobbies and interests... For German students, to choose a dormitory to reside is to choose their favorite "group" and choose a unique value concept and lifestyle. In such way, an organic connection is built among lodgers and the sense of identity of a group is more obvious". (Qing, Mu, 2004) A unified and top-down management model is a primary reason for single function and indifferent emotional exchange in Chinese college student dormitories. In the current management model, students are the object of management and monitoring. Each student is confined to extremely narrow space, so both physical space and social space are lacking. If we say that physical space is subject to historical construction and funds input so as to be difficult to get improved within a short period of time, then social pace is totally dependent upon people's concept and capacity. As mentioned previously, communication in reality in student dormitory is extremely infrequent and students have high expectations on interpersonal relationship in the dormitory. If a variety of academic and non-academic exchange activities are carried out in the dormitory, it might be helpful for students to construct an organic interpersonal relationship network in the dormitory and, therefore, produce a sense of identity and a sense of belonging for the dormitory. To achieve this target, the current dormitory management model needs to be consistent with transformation of the entire university management model and be transformed to a governance model. The so-called governance "is the sum of a variety of methods in which an individual or organization and a public sector or private sector governs its general affairs. It is a continuous process in which conflicts and multiplex interests get compromised and 
cooperative behaviors are done". (Commission on Global Governance, 1995, p.2) As the previous survey presents, college student dormitory is a venue in which conflicts and multiplex interests are extremely abundant. Traditional public administration results in sameness of each dormitory building and even each room, lacking in individual features and characteristics. Besides, it is a usual practice and unique choice to hold down conflicts and neglect the multiplex interests of students to achieve the low level of "no accident". As a result, it is difficult to help students realize development in several aspects. Therefore, it is necessary for the universities to formulate dormitory management norms that allow students to participate in decision making and change students from an object of management to a subject of participating in governance. This helps to push college student dormitory to grow up to "a community of learners". Here, "an individual... must be able to re-establish a new learning partnership, again and again." (Michael Fullan, 2004, p.67) In order to carry out such a participation governance system, it is inevitable to set up a corresponding organizational system. It is true that a lot of issues in college dormitory management might not be directly empowered to students and can only be determined by senior managerial personnel, but it is totally possible to adopt the mode of participation decision making in resolving issues correlated with students. In such way, opinions of students, "the stakeholder", can be regarded as a reference to a correct decision making. Therefore, transformation of student dormitory management should be consistent with the process of the entire higher education reform, and is an organic component of the system in modern university. In addition, both change of concepts and design of system are required. The technical means can be realized by the network means which are widely accepted among university students. A person is always a social one, so university students need to learn how to learn, how to handle things, how to behave themselves and how to get along well with others in their life in college dormitories.

4.3 Finally, It Is Necessary to Set up a Dormitory Educational System and Create a Variety of Opportunities Which Are Helpful to Individual Growth and Development

It is indicated in the questionnaire survey, students are relatively satisfied with the service work of college student dormitory management, while they are dissatisfied with a series of mandatory management stipulations. This is, as a matter of fact, students' real attitudes towards "the logistics socialization" in Chinese universities in recent years. They believe that the service level has been improved, but the educational influences have been crippled. Modern educational idea requires that education returns to "the living world". (Xiang, Xianming, 2002, p.223) Thus, it is necessary to carry on education in actual life and provide guidance of lifestyle and dormitory is, of course, an important battle field. Currently, management of university student dormitory in quite a large number of countries and regions is a necessary component of the entire general education system. For instance, it is believed that college student dormitory is a component of the educational institution in Hong Kong University of Science and Technology. In this university, student dormitory is an important carrier in implementing holistic education and usually a professor holds the role of dormitory supervisor. Establishing a complete self-governance organization within a dormitory and carrying out independently a variety of activities help to form a unique culture of a dormitory. "Student dormitory is not merely the 'home' of the students during their pursuit of study, but also extension of such learning venues as classroom and library and the major battlefield of ideological and cultural exchange among students". (Ma, Donghui \& Xiong, Xiangtao, 2005, p.37) It is necessary to learn advanced experiences in other countries and regions. College student dormitory management in mainland regions in China should also break through restrictions of socialization and marketization and regard student dormitory as a real occasion for integration of rest, learning and education. A complete dormitory educational system can be established by means of personnel allocation, institutional design and activity arrangement to attempt to provide each student with opportunities for personal growth and development.

\section{References}

Commission on Global Governance. (1995). Our Global Neighborhood: The Report of the Commission on Global Governance, p.2. Oxford University Press.

Cui, D. F. (2019). Application of Smart Home in Safety Management of College Dormitories. Modern Information Technology, (02), 25.

Fullan, M. (2004). Change Forces: Probing the Depths of Educational Reform, p.67. Translated by National Institute of Education Sciences and Toronto International College. Beijing: Educational Science Publishing House.

Gang Piaoyi Station. (2017, December 11). In the International Daze Competition, it was unexpected that the boy of HKUST won the championship. Sohu News.

Gao, B. (1998). Brief Summary of Theoretical Development of Studies on Western Lifestyle. The Study of Sociology, (3), 61. 
Hou, C. H. (2019). On the Effective Integration of Dormitory Management and Ideological and Political Education in Colleges and Universities. A Comparative Study of Cultural Innovation, (02), 11.

Li, Z. Z., Guo, X., Jiang, F. Y., \& Liu, J. Y. (2019). Analysis on the adjustment of winter indoor environment in a university dormitory in the North. Building Thermal Energy, Ventilation and Air Conditioning, (4), 54.

Ma, D., \& Xiong, X. (2005). Guide and Management of College Student Dormitory in the Hong Kong University of Science and Technology. Higher Education Exploration, (3), 37.

Marx, K., \& Engels, F. (1972). Feuerbach. Marx Engels Selected Works (Volume 1, p.25). People's Publishing House.

Office of Education, Thought and Politics. (2004). Notice on Conscientiously Strengthening College Student Dormitory Management by the Ministry of Education, No. 6 .

Office of Education, Thought and Politics. (2005). Notice on Conscientiously Strengthening College Student Dormitory Management by the Ministry of Education, No. 4.

Office of Education, Thought and Politics. (2007). Notice on Conscientiously Strengthening College Student Dormitory Management by the Ministry of Education, No. 4.

Qing, M. (2004, November 8). German University Dormitories as a Home, With Low Price, Complete Functions and Autonomous Management (24th ed.). Global Times.

Xiang, X. (2002). Pan-education Theory, p.223. Taiyuan: Shanxi Education Publishing House.

Xu, B., \& Cang, Y. (2004). A Historical Analysis of Education in University Dormitories: Dormitories and Talent Cultivation. Fudan Education Forum, (12), 96.

Yan, X., Hu, T., \& Liu, D. (2006). Application of Higher Education Idea in Planning of University Campus Construction. Modern University Education, (1), 72.

Yang J. B. (2018). Campus-based Management of College Students'Dormitories. Curriculum Education Research, (04), 82.

Zhu, L., \& Xie, J. (2013, May 9). Splitting Campus Wound by the Poisoning Case in Fudan University and Inharmonious Relationships in Dormitories in Multiple Universities. China Youth News.

\section{Copyrights}

Copyright for this article is retained by the author(s), with first publication rights granted to the journal.

This is an open-access article distributed under the terms and conditions of the Creative Commons Attribution license (http://creativecommons.org/licenses/by/4.0/). 